\title{
Geochemical Relations which reflect the History of Kimberlites from the Type area of Kimberley, South Africa.
}

\section{G. W. Berg}

Dept. of Geological Sciences, University of Cape Town, Rondebosch 7700, South Africa.

The bulk chemistry and petrography of some 70 fresh, altered and contaminated kimberlites have been studied to contribute to the goal set by Mitchell (1986) "....to deconvolute the evidence presented to us and seek out the primitive kimberlite magma". The bulk analyses yielded a series of inter-element relations which reflect a sequence of recognisable events, each of which further obscures the original chemistry of primitive kimberlite.

The relation of the two most abundant elements in kimberlite, $\mathrm{MgO}$ and $\mathrm{SiO}_{2}$ (Fig 1) reveals two broad tends. The positive correlation, observed for hypabyssal kimberlites, is interpreted to reflect:

a.) The most primitive kimberlite analysed (KDT=Dutoitspan macrocrystic monticellite kimberlite);

b.) Sparsely macrocrystic and aphanitic kimberlites formed by loss of olivine macrocrysts (and

diamonds?) from macrocrystic kimberlite; and,

c.) Possible events at the kimberlite source, discussed later.

The negative correlation trend of altered kimberlites (mainly TKB's) reflects contamination by country rock, modeled in Fig 1 as Ecca shale, analysed by Danchin (1970). The deficiency of MgO in TKB's, compared to the mixing line between Dutoitspan "primitive" kimberlite and shale, is ascribed in part to the loss of $\mathrm{MgO}$ in solution during open system alteration (see Berg, 1989).

The concentration of $\mathrm{Al}_{2} \mathrm{O}_{3}$ and/or the relation of $\mathrm{SiO}_{2}$ to $\mathrm{Al}_{2} \mathrm{O}_{3}$ (Fig 2) has been widely used to assess contamination of kimberlite by country rock (eg Mitchell 1986 and refs therein). Fig 2 supports the interpretation of Fig 1 that contamination by shale has occurred in the altered kimberlites. Fig 2 further reveals that the box of “...contamination free(?)" kimberlite of Mitchell (1986, fig 7.1) includes numerous analyses of altered and contaminated rocks. The maximum concentration of $2.2 \% \quad \mathrm{Al}_{2} \mathrm{O}_{3}$ found in fresh hypabyssal Dutoitspan monticellite kimberlite is proposed here as a maximum for uncontaminated Type I kimberlite. Detailed petrographic examination, however, when considered together with Fig 2, suggests that minor $\mathrm{Al}_{2} \mathrm{O}_{3}\left(\right.$ and $\left.\mathrm{Na}_{2} \mathrm{O}\right)$ in some of the KDT samples may be derived from "kimberlitised" shale. Analysis 1 of Berg and Carlson (this volume) may better reflect truly uncontaminated Type I kimberlite. Fig 2 cannot be used to simultaneously assess contamination of Type I and Type II (micaceous) kimberlites. The latter need to be treated separately because their generally higher phlogopite contents can introduce primary aluminium in excess of that observed in uncontaminated Type I kimberlites.

The concentration of $\mathrm{Na}_{2} \mathrm{O}$ has also been considered as a measure of contamination of kimberlite (eg Clement et al 1984). $\mathrm{Al}_{2} \mathrm{O}_{3}$ was therefore related to $\mathrm{Na}_{2} \mathrm{O}$ in the expectation that high concentrations of $\mathrm{Na}_{2} \mathrm{O}$ would relate to $\mathrm{Al}_{2} \mathrm{O}_{3}$ on a shale mixing line (Fig 3). It is clear from Fig 3 , however, that the concentrations of $\mathrm{Na}_{2} \mathrm{O}$ in highly contaminated kimberlites are in excess of the amount introduced by shale, and reflect yet a later event. Relations of $\mathrm{Na}_{2} \mathrm{O}$ with other elements were therefore investigated with a view to identifying the host mineral of sodium in the highly altered rocks. Surprisingly, the closest correlation with $\mathrm{Na}_{2} \mathrm{O}$ was found to be with $\mathrm{H}_{2} \mathrm{O}$, that is to say, loosely bound water. However, careful microbeam study revealed only two sodic minerals; these are pectolite, first discovered in kimberlite by Scott-Smith et al (1983), and Ti-rich acmite, grading into aegerine augite, briefly reported by Berg (1990) and further detailed in the poster accompanying this abstract. The $\mathrm{Na}_{2} \mathrm{O}$ vs $\mathrm{SiO}_{2}$ relation (Fig 4) is consistent with the location of $\mathrm{Na}_{2} \mathrm{O}$ in these minerals. 
The suspected relation of clay volumes $\left(\mathrm{H}_{2} \mathrm{O}^{-}\right)$to $\mathrm{Na}_{2} \mathrm{O}$ concentrations may quantitatively reflect part of the process of formation of the sodic minerals. The "excess" sodium with respect to shale is interpreted to reflect metasomatic addition by post-emplacement water circulation.

Further interpretation of the chemistry of the KDT (most primitive) kimberlite is made on the premise, based on petrography, that the macrocrystic olivines in this kimberlite are derived from mantle peridotite; that most of the orthopyroxene in this peridotite was dissolved in the primary kimberlite fluid; and that the rounded form of many macrocrysts compared to the form of olivine in mantle peridotite implies that there was some dissolution of olivine into the proto-kimberlite as well. The chemical components of this olivine may report back at a late stage in groundmass microphenocrysts. The dissolved orthopyroxene, in turn, is speculated to report back in monticellite, the mass balance equation being: $\mathrm{MgSiO}_{3}+\mathrm{CaCO}_{3} \rightarrow \mathrm{CaMgSiO}_{4}+\mathrm{CO}_{2}$. More direct evidence for the operation of this reaction is found in the formation of monticellite in the alteration halos of rare residual orthopyroxenes, which are clearly in disequilibrium in the kimberlite at a late stage when it was precipitating olivine microphenocrysts or monticellite.

The maximum amount of peridotite that can be modeled to have been incorporated in a kimberlite in the form of olivine macrocrysts and molten/reacted pyroxene can be estimated from variation diagrams on the basis of the lever rule. Thus Fig 1 in isolation would suggest that the Dutoitspan kimberlite might consist of a maximum of about $70 \%$ of average peridotite and $30 \%$ of a Si-free phase carrying about $15 \% \mathrm{MgO}$. Analogously Fig 5 would suggest a limit of about $70 \%$ peridotite with $30 \%$ of a phase free of both $\mathrm{SiO}_{2}$ and $\mathrm{Cr}_{2} \mathrm{O}_{3}$. These "end member" estimates are not definitive, but reference to the kimberlite analyses themselves can indicate limits as to what the composition of the minimum "non-peridotitic" component of kimberlite might be. A typical Dutoitspan kimberlite analysis such as KDT 25 (Berg and Carlson, this volume) has concentrations of $\mathrm{K}_{2} \mathrm{O}, \mathrm{CO}_{2}, \mathrm{TiO}_{2}$ and $\mathrm{P}_{2} \mathrm{O}_{5}$ equivalent to approximately $10 \%$ phlogopite, $8 \%$ calcite, $3 \%$ ilmenite and $2 \%$ apatite. Together with water, these "kimberlitic" minerals add up to about $30 \%$ of the KDT kimberlite. The chemical constituents of these minerals are present in relatively insignificant amount in the four definitive silicate phases of garnet lherzolite. It is logical, therefore, to search for them in metasomatised peridotites to find a model source for kimberlite. This subject is addressed by Berg (this volume), with particular reference to carbonate.

\section{References}

Berg G W (1989) The significance of brucite in South African Kimberlites. 4th International Kimberlite Conference, Geological Society of Australia, Special Publication 14, 282-296.

Berg (1990) Aegerine and the geochemistry of sodium in kimberlite. Geocongress 1990, Cape Town, Abstr. p 45.

Clement C R, Skinner E M W and Scott-Smith (1984) Kimberlite Redefined. Journ. Geol. 92, 223228.

Danchin R V (1970) Aspects of the geochemistry of some selected South African fine grained sediments. PhD Thesis, University of Cape Town.

Mitchell R H (1986) Kimberlites. Plenum Press.

Scott-Smith B H, Skinner E M and Clement C Roger ((1983) Further data on the occurrence of pectolite in kimberlite. Min Mag 47, 75-78. 

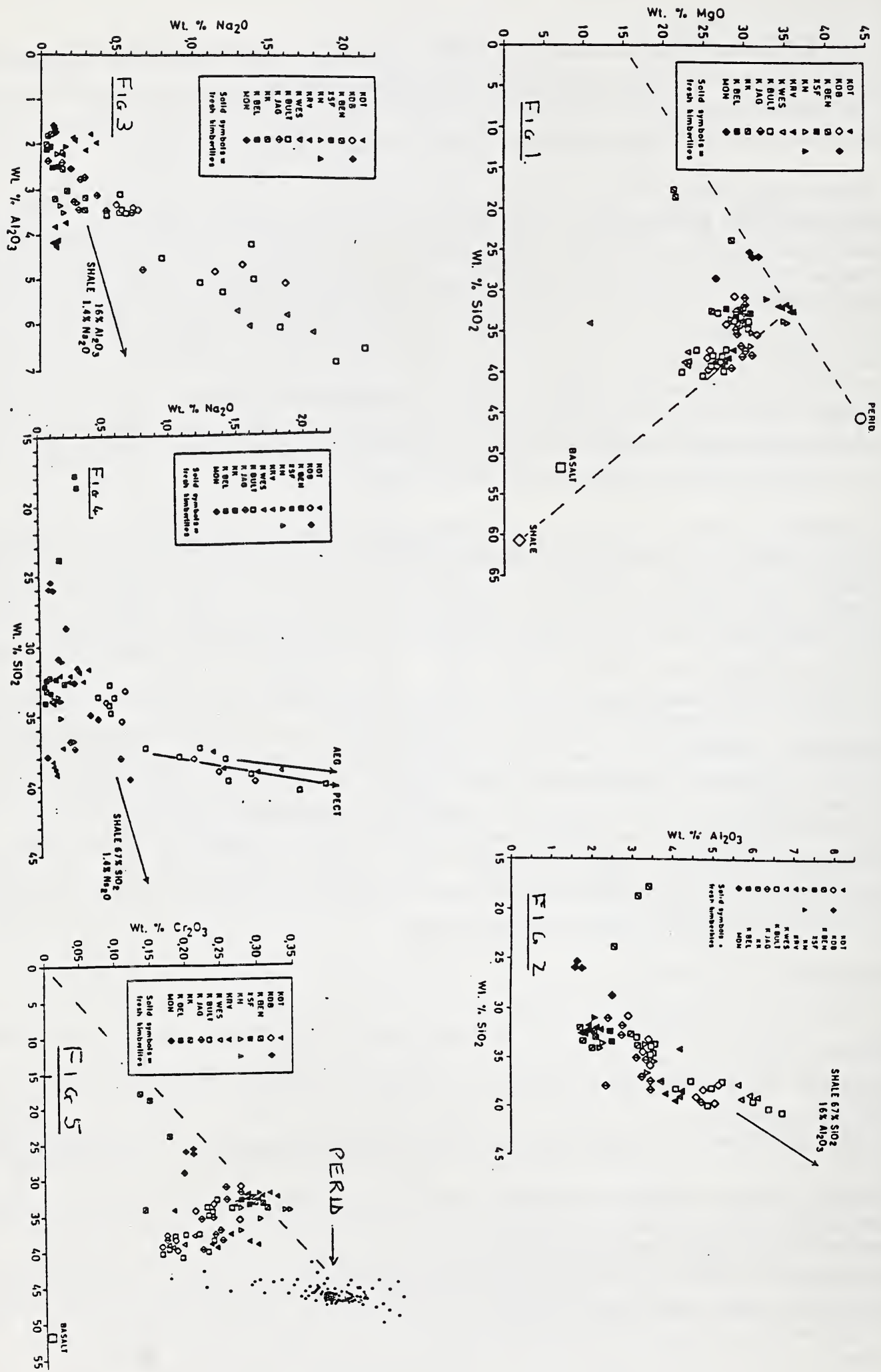